\title{
Article \\ A GIS-Based Analysis of the Light Rail Transit Systems in Spain
}

\author{
Estela Pantiga-Facal and Pedro Plasencia-Lozano *
}

Citation: Pantiga-Facal, E.; Plasencia-Lozano, P. A GIS-Based Analysis of the Light Rail Transit Systems in Spain. Appl. Sci. 2022, 12, 1282. https://doi.org/10.3390/ app12031282

Academic Editors: Sanda Roșca, Ștefan Bilașco, Dănuț Petrea, Titus Cristian Man and Paul Sestras,

Received: 5 December 2021

Accepted: 21 January 2022

Published: 25 January 2022

Publisher's Note: MDPI stays neutral with regard to jurisdictional claims in published maps and institutional affiliations.

Copyright: (c) 2022 by the authors. Licensee MDPI, Basel, Switzerland. This article is an open access article distributed under the terms and conditions of the Creative Commons Attribution (CC BY) license (https:/ / creativecommons.org/licenses/by/ $4.0 /)$.
Department of Construction and Manufacturing Engineering, University of Oviedo, 33600 Mieres, Spain; estela.pantigafacal@gmail.com

* Correspondence: plasenciapedro@uniovi.es

\begin{abstract}
Throughout the last decades, light rail transit systems (LRT) have been built around the world due to their strengths: regularity, savings in $\mathrm{CO} 2$ emissions, flexibility, image and optimization of urban space. This research proposes the analyses of a group of LRTs by using a method supported by GIS. Some data and parameters have been stated in order to define the systems. The range of values obtained allow us to characterize the LRT systems operating in Spain: for instance, mean distance range between stations is $405 \mathrm{~m}$ to $685 \mathrm{~m}$, and potential users range (people who live no more than $500 \mathrm{~m}$ from a station) is 18,000 to 30,000 , and population density in the capture areas is never below 1514 pop $/ \mathrm{km} 2$ (in cities with no metro system). The benefit of the present study is to establish common data values that could be useful in future studies and preliminary projects carried out in other Spanish cities interested in introducing an LRT in their urban grid, and also for comparison with LRT in other countries. The method could be also applied to other public transportation systems, and to other countries.
\end{abstract}

Keywords: LRT; TOD; QGIS; public transportation; country analysis

\section{Introduction}

In recent years, numerous light rail transit (LRT) system projects have been undertaken in Spain, as in other nearby countries, such as Portugal, United Kingdom, France and Greece, after the success of the Nantes tram inaugurated in 1985, which for many marks the beginning of the renaissance of this transportation mode [1-3], and in other places, such as the United States [4]. Since 1994, LRT systems have been put into service in 11 Spanish metropolitan areas (Figures 1 and 2). Some are core elements of the urban transit system (Zaragoza or Tenerife), while others complement more complex structures with greater capacity, such as the schemes around Madrid, such as Boadilla and Parla. There is evidence that such systems have been proposed in other places such as Pamplona [5], and in some cities there are well-advanced works for their future installation, such as in Cadiz and Jerez de la Frontera [6]. LRT systems are excellent for their regularity, savings in $\mathrm{CO}_{2}$ emissions, flexibility, image and optimization of urban space [7], and they have positive effects on urban growth and quality of life [8-10], and also increase active travel [11].

As mentioned elsewhere, for an LRT system to be successful in a consolidated urban context, it must be preceded by careful planning combining cost, potential user, travel time and frequency studies, in order to choose the best possible alternative [3,12-14].

In this study, we applied QGIS open software to collect core data on potential and real users of LRTs in Spain, as well as other parameters related to urban geometry. With it, we were able to evaluate acceptance of each system along with other data referring to the systems evaluated here. The main objective, and therefore the research question, is the determination of a range of values for some parameters that characterize the various LRTs operating in Spain, in order to establish model values that can be used in future studies and preliminary projects in other Spanish cities showing interest in introducing LRTs in their urban grid. In addition, this study is the basis for future more detailed studies combining 
the results found here along with other variables that could predict future acceptance of other LRTs under study.

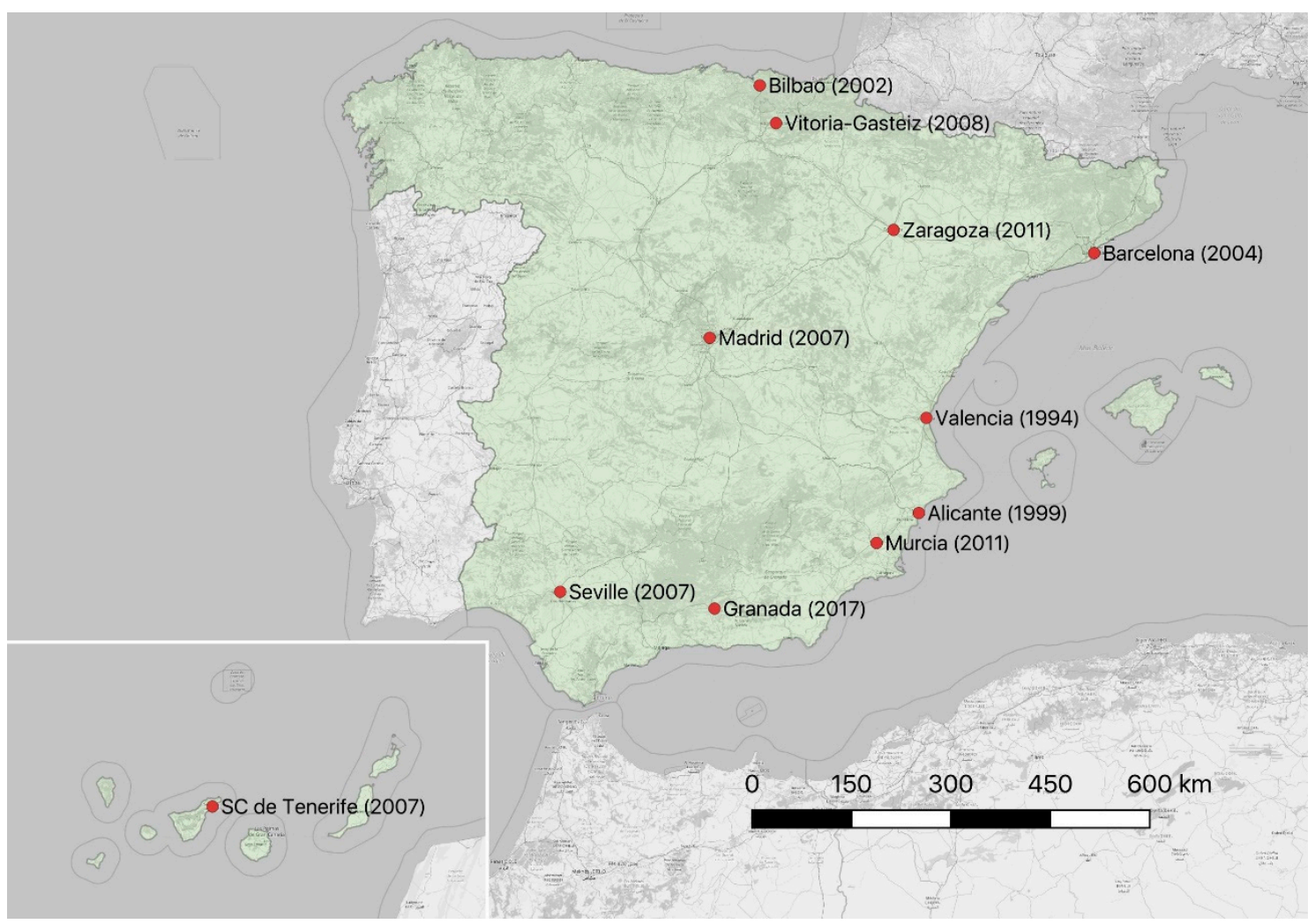

Figure 1. Cities with LRT and year inaugurated. Barcelona includes the Trambaix and Trambesòs systems; Madrid includes the Pozuelo, Boadilla, Sanchinarro and Parla systems.

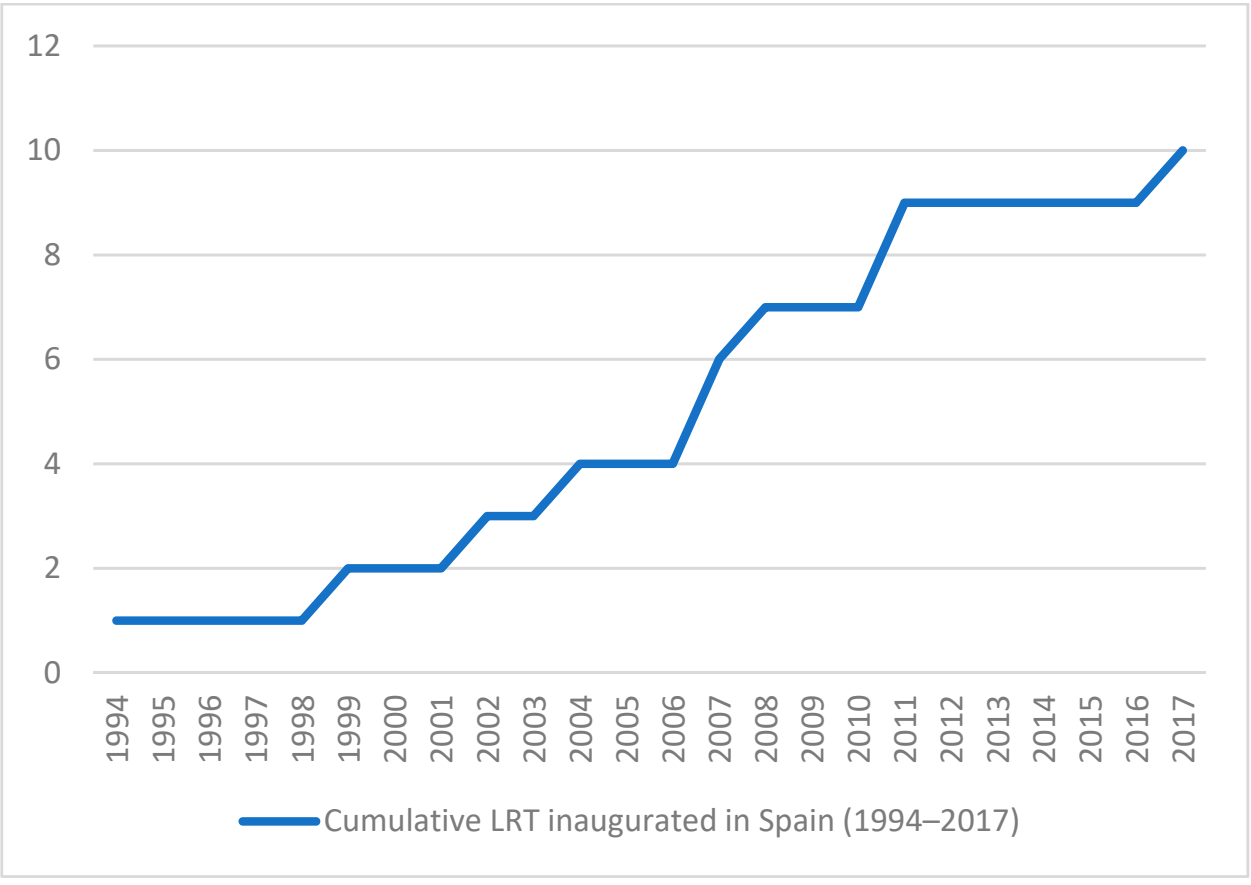

Figure 2. Cumulative LRT inaugurated in Spain (1994-2017). 


\section{Literature Review}

The European Conference of Ministers of Transport has defined light rail as a rail-borne form of transport that can be developed in stages ranging from the modern tram to a rapid transport system operating on its own right of way, be it underground, at ground level, or elevated [15,16]. Ideally, light rail is a form of railway urban transportation system, that is not a heavy traditional form of railways. The interest for LRT systems in the whole world has been increased in the last years, and relevant projects have been conceived and therefore analyzed in Europe [15,17], Africa [16,18], Asia [19,20], Australia [21,22] or America [23,24].

The reason for its relevance can be found in its advantages. LRT contributes to reduce the local atmospheric pollution and, in general terms, operates against the global warming [25]. Moreover, the reduction of car trips from overcrowded roads, another consequence of new LRT schemes, offer new spaces for pedestrians and therefore promotes active travel [26-28], although it could generate accidents if the stations surroundings are not well designed [29]. In terms of economics effects, new LRT systems have been linked to the generation of new business in the city [30] and to the increase of property values [31]; furthermore, positive impacts on labor market accessibility has also been detected [32]. Finally, new projects cultivate an image of a city or region as progressive and modern, which is also positive for tourism $[33,34]$.

However, in some places new LRT schemes have failed, such as the Groningen RegioTram [35], the Tel Aviv LRT [36] or different cities in Britain. Some research have reported that the reason for the lack of interest for using rail transit is the failure for providing the expected level of quality service $[37,38]$. Thus, clients not satisfied with the service would not be loyal to the service and would not recommend it to others [39]. Some papers have attempts to investigate the factors influencing the satisfaction of rail transit passengers based on the evidence from the light rail transit [40]. In this sense, it has been identified that an indicator of a successful public transport service is the number of passengers that the system is able to retain and attract $[39,41]$. Some factors which have been identified for dissuading the use of rail transport systems are lack of connection, access distance to and from stations, or distance to/from home-work [42,43]; elsewhere, transfer penalty has been stated as a key consideration in the ridership potential of a public transport system [44]. In Spain, in particular, several very significant infrastructures planned and built in recent years with certain users forecast, have, however, later proven to be oversized [45]. One of these was the Jaen LRT, which was inaugurated in 2011 and had to be closed a few days later because of administrative and financial problems [46]. As a consequence, some cities previously interested in developing LRT schemes have stopped their projects, such as Vigo or A Coruña $[47,48]$. Therefore, it becomes especially important to know the characteristic parameters of the LRTs operating in Spain. This will be useful in future studies and drafts carried on in other Spanish cities interested in introducing an LRT in their urban grid.

The search for parameters characterizing LRT systems is not new: In Busan, an attempt was made to define concrete parameters, such as walking distance from the LRT [49], Casello collected some of the main characteristics of LRTs in North America [12], and similar studies have been carried out in Turkey [50,51] with numerous parameters, such as number of passengers per kilometer, number of passengers carried per unit length of line, number of passengers carried per number of stations, or the daily number of passengers per urban population. Van Oort also made a description of the main European schemes [52]. In Spain, the Observatorio de la Movilidad Metropolitana [Polytechnic University of Madrid Mobility Observatory] has collected some valuable data, mainly from the transportation companies themselves [53]. Economic analyses have also been carried out [54], and some lines have been the subject of previous studies, such as the LRT in Granada [55-57], which included details such as population density near stops among other parameters related to transit-oriented development (TOD) analysis.

On another matter, the use of Geographic Information Systems for transportation system analysis has become generalized. Thus, use of GIS has recently been gaining in strength for the study of capture areas [58,59]. A station's capture area may be defined 
as the urban space or territory that potential users are going to come from. Traditionally, citizens have been thought to be willing to walk a maximum time or distance from their homes or trip's point of origin to a public transportation station and the capture area is the space between the station and the limit of that time or that maximum distance. Studies have shown the complexity of defining that capture area for a specific station, as many parameters enter into it, such as demographic [60] or urban design characteristics [61-63], and therefore, there are specific methods for determining exactly what this area is at a particular station, such as surveys [64] or ride cards [65]. However, in macroanalyses related to planning or a complete transportation system, the area is usually reduced to the portion of the city included within a circle with its center at each station in the system. This simplification requires, in turn, setting the radius of each circle, and in the literature, for LRTs this would vary from $400 \mathrm{~m}$ or 0.25 miles $[66,67]$ to $800 \mathrm{~m}[68,69]$, although it is accepted that in the outskirts, citizens are willing to go further [70]. We might note that, in Spain, the usual distance is $500 \mathrm{~m}$ [56,71]. Beyond the capture areas, the GIS has also been used to acquire data on the density of stops or stations [72,73], stop spacing [74], land use [75] or road lengths [76]. Furthermore, GIS has be used to ascertain the "attraction nodes" (e.g., offices, tourist attractions, and hotels) within a broad area [77] or to identify the hotspots of the healthcare services in a territory [78], and GIS applications pertinent to the field of transportation engineering were developed [79] to analyze the impact of activity trips on regional transportation patterns. Moreover, some researchers have used GIS for developing multicriteria studies linked to public transport or even light rail system topics. Prasertsri and Sangpradid analyzed the appropriateness of parking site selections around LRT stations for the customers [80]. Farooq et al. [81,82] used GIS as a tool for their development of a transportation model between Beijing and XiongAn. It has therefore been shown to be a useful tool for finding parameters related to transportation networks.

In brief, LRT systems are in ascendant in numerous countries. The main advantages have been established; moreover, the existence of failed projects has been well described, regularly linked to problems related to urban and LRT scheme geometry, as stations. Furthermore, research on the description of LRTs through parametrical characterization has been carried on in different occasions; finally, the rise of GIS for developing research on transportation systems, and in particular on urban geometry in the stations surroundings is a fact. For that, research on Spanish LRTs for characterizing the ongoing schemes through the determination of the values of different parameters and ratios, linked to urban geometry and users' densities in the catchment areas can be interesting. An expected benefit is the determination of values for helping authorities and planners to develop future projects; moreover, current schemes may be analyzed in order to establish possible explanation of their success or failure.

\section{Study Area}

This section may be divided by subheadings. It should provide a concise and precise description of the experimental results, their interpretation, as well as the experimental conclusions that can be drawn.

There are LRTs in 11 metropolitan areas in Spain. In five of them, they have become the main public transportation system in the city. In the other five, the LRT coexists with the conventional subway, and therefore, its function is to complement the city's public transportation system as another subway line (as in Barcelona or Bilbao) or sometimes as a system feeder (Madrid, for example). Finally, one of them, Alicante, is a tram-train. It seems logical, therefore, to separate the LRTs into three groups based on their importance within the total metropolitan transportation system. We also note that two new systems are expected to be inaugurated soon: the tram-train in Bay of Cadiz [6] and the light rail transit system in Jaen (Type I), which was completed in 2011 and will be put soon into service after overcoming a diversity of administrative problems. Some other cities as Gijón are working on developing a metropolitan rail system, although for the moment it is not clear if it will be a tram-train, a conventional metro or a LRT [83]. 


\section{Materials and Methods}

The study was carried out by following the steps below (Figure 3):

1. Analysis of previous studies and background. A bibliographic search was made in the main internet sites related to LRT on these topics: advantages and individual LRT in Spain, groups of LRTs in other countries, parametric and geographic analyses of metropolitan public transportation systems, and GIS as a tool for transportation systems.

2. Analysis of the sample. The LRTs to be evaluated were determined and divided into subgroups by whether or not there were conventional subway systems in the city itself.

3. Data and parameters to be evaluated in the study were defined: the sources cited in the literature review section were checked, and a list was determined (Table 1): Annual service users; line length; number of lines, number of stations, number of shared stations; capture area; potential users; daily users; users per station; acceptance rate; density of capture area; mean distance between stations; passengers per unit line.

4. Data processing with QGIS.

a. Geometrical data (LRT lines and stations) were drawn

b. A shape with data from official census was included. Some lab work was carried out in order to obtain the population density in each census section.

c. Catchment areas around the station were drawn. For that, a buffer zone with $500 \mathrm{~m}$ radius was stated (Figures 4 and 5).

d. Finally, some parameters values were obtained: Line length; number of lines, number of stations, number of shared stations; capture area; potential users; mean distance between stations; passengers per unit line. The population affected in each catchment area was determined under the assumption that the population in each census area (minimum area for which there are census data) is uniformly distributed within each area. Furthermore, the population data was taken from the official 2017 census.

5. Results are defined in different tables.

a. Beyond the data referred in the previous step, annual service users' data were taken from the operators' 2017 annual reports (Table 2). Finally, documents of the Polytechnic University of Madrid Mobility Observatory were checked [53].

b. Ratios were defined after the aforementioned data: daily users; users per station; acceptance rate; density of capture area; passengers per unit line.

6. Discussion and conclusions. The values found were analyzed, and the main conclusions of the study were outlined.

Table 1. Parameters and ratios of the study.

\begin{tabular}{ccc}
\hline & & Description \\
\hline 1 & Annual service users (million pax) & \\
2 & Line length (km) & \\
3 & Number of lines (units) & \\
4 & Number of stations (units) & \\
5 & Number of shared stations (units) & Urban area within 500 m of a station \\
7 & Capture area $\left(\mathrm{km}^{2}\right)$ & Population of the capture area \\
8 & Potential users (pop) & $\frac{\text { annual users }(\mathrm{pax})}{280}$ \\
9 & Daily users (pax) & $\frac{\text { daily users }(\mathrm{pax})}{\text { stations }}$ \\
10 & Users per station (pax) & $\frac{\text { daily users }(\mathrm{passengers})}{\text { potential users (passengers) }}$ \\
11 & Acceptance rate & $\frac{\text { potential users }(\mathrm{pax})}{\text { capture area }\left(\mathrm{km}^{2}\right)}$ \\
13 & Density of capture area $\left(\frac{\mathrm{pax}}{\mathrm{km}^{2}}\right)$ & $\frac{\text { passengers }(\mathrm{pax})}{\text { total length }\left(\mathrm{km}^{2}\right)}$ \\
\hline
\end{tabular}


Table 2. Data sources for daily users.

\begin{tabular}{|c|c|c|}
\hline Group & City & Data Source \\
\hline \multirow{5}{*}{$\mathrm{I}$} & Granada & $\begin{array}{c}\text { https:/ / metropolitanogranada.es/noticias / Balance_2018 } \\
\text { Metro Granada (accesed on } 30 \text { November 2021) }\end{array}$ \\
\hline & Murcia & $\begin{array}{c}\text { https://www.tranviademurcia.es/ (accesed on } \\
30 \text { November 2021) }\end{array}$ \\
\hline & Santa Cruz de Tenerife & $\begin{array}{l}\text { https: / / metrotenerife.com/MEMORIAS/2017/index.html } \\
\text { (accesed on } 30 \text { November 2021) }\end{array}$ \\
\hline & Vitoria & $\begin{array}{c}\text { https:/ / www.gasteizhoy.com/tranvia-vitoria-usuarios/ } \\
\text { (accesed on } 30 \text { November 2021) }\end{array}$ \\
\hline & Zaragoza & $\begin{array}{l}\text { https: / / www.zaragoza.es/contenidos/movilidad/transporte- } \\
\text { alta.pdf (accesed on } 30 \text { November 2021) }\end{array}$ \\
\hline \multirow{5}{*}{ II } & Barcelona & $\begin{array}{c}\text { https: / / www.vialibre-ffe.com/noticias.asp?not }=26849 \\
\text { (accesed on } 30 \text { November 2021) }\end{array}$ \\
\hline & Bilbao & $\begin{array}{l}\text { https:/ / www.euskotren.eus / sites/default/files/2019-01/ } \\
\text { Euskotren\%20sigue\%20creciendo\%20en\%20todas\%20sus\%20 } \\
\text { unidades\%20operativas.pdf (accesed on } 30 \text { November 2021) }\end{array}$ \\
\hline & Madrid & $\begin{array}{c}\text { https:/ / www.crtm.es/media/880193/informe_anual.pdf } \\
\text { (accesed on } 30 \text { November 2021) }\end{array}$ \\
\hline & Seville & $\begin{array}{l}\text { https: / /www.diariodesevilla.es/sevilla/tranvia-Sevilla-sigue- } \\
\text { perdiendo-viajeros-Tussam-gana_0_1400860373.html (accesed } \\
\text { on } 30 \text { November 2021) }\end{array}$ \\
\hline & Valencia & $\begin{array}{l}\text { https:/ / habitatge.gva.es/es/inicio/area_de_prensa/not_ } \\
\text { detalle_area_prensa?id=733558 (accesed on } 30 \text { November 2021) }\end{array}$ \\
\hline III & Alicante & $\begin{array}{c}\text { https://es.wikipedia.org/wiki/Anexo: } \\
\text { Estad\%C3\%ADsticas_del_TRAM_Metropolitano_de_Alicante } \\
\text { (accesed on } 30 \text { November 2021) }\end{array}$ \\
\hline
\end{tabular}
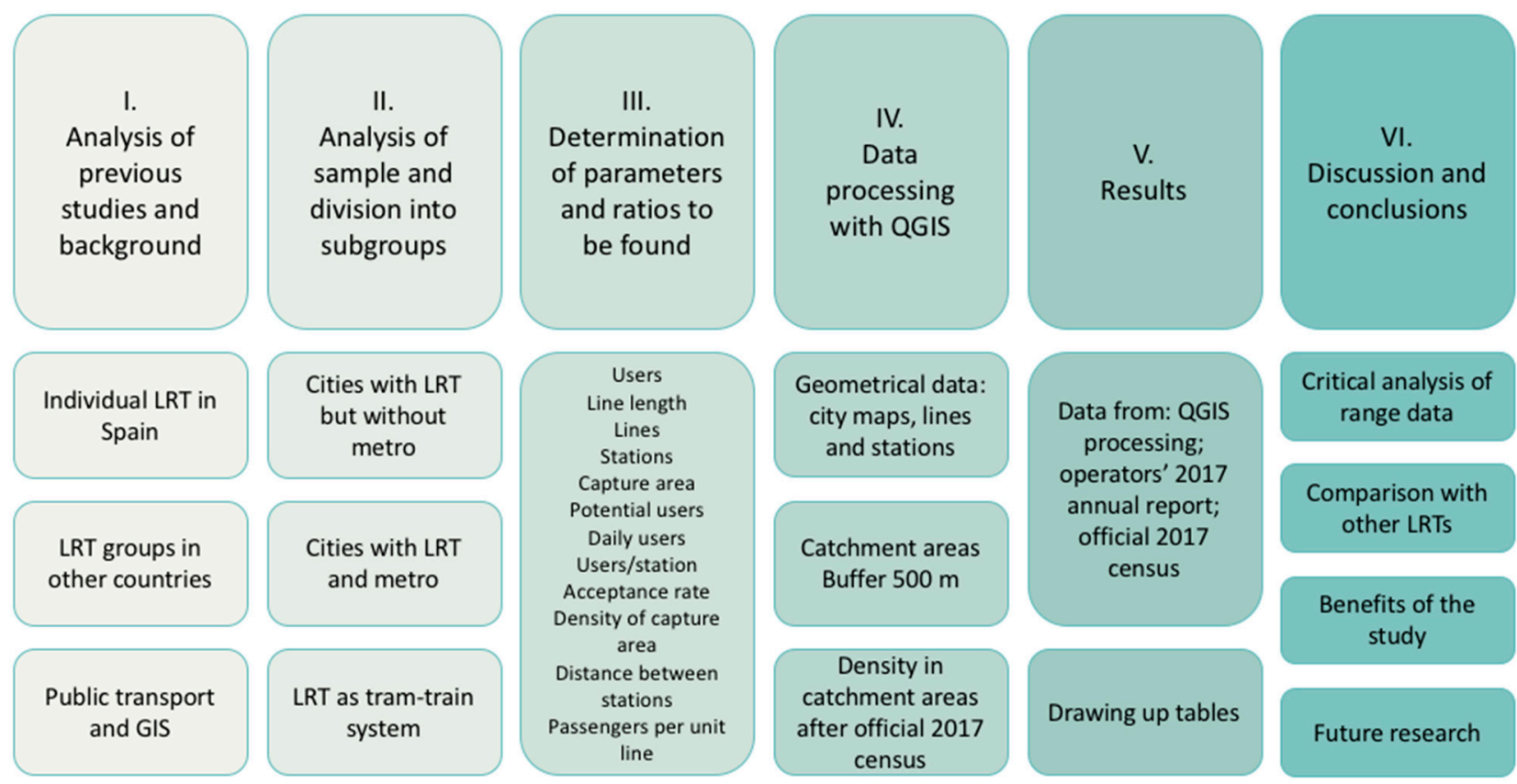

Density in

catchment areas

after official 2017 census
Comparison with other LRTs

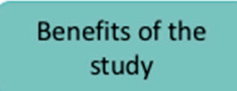

Future research

Figure 3. Method. 

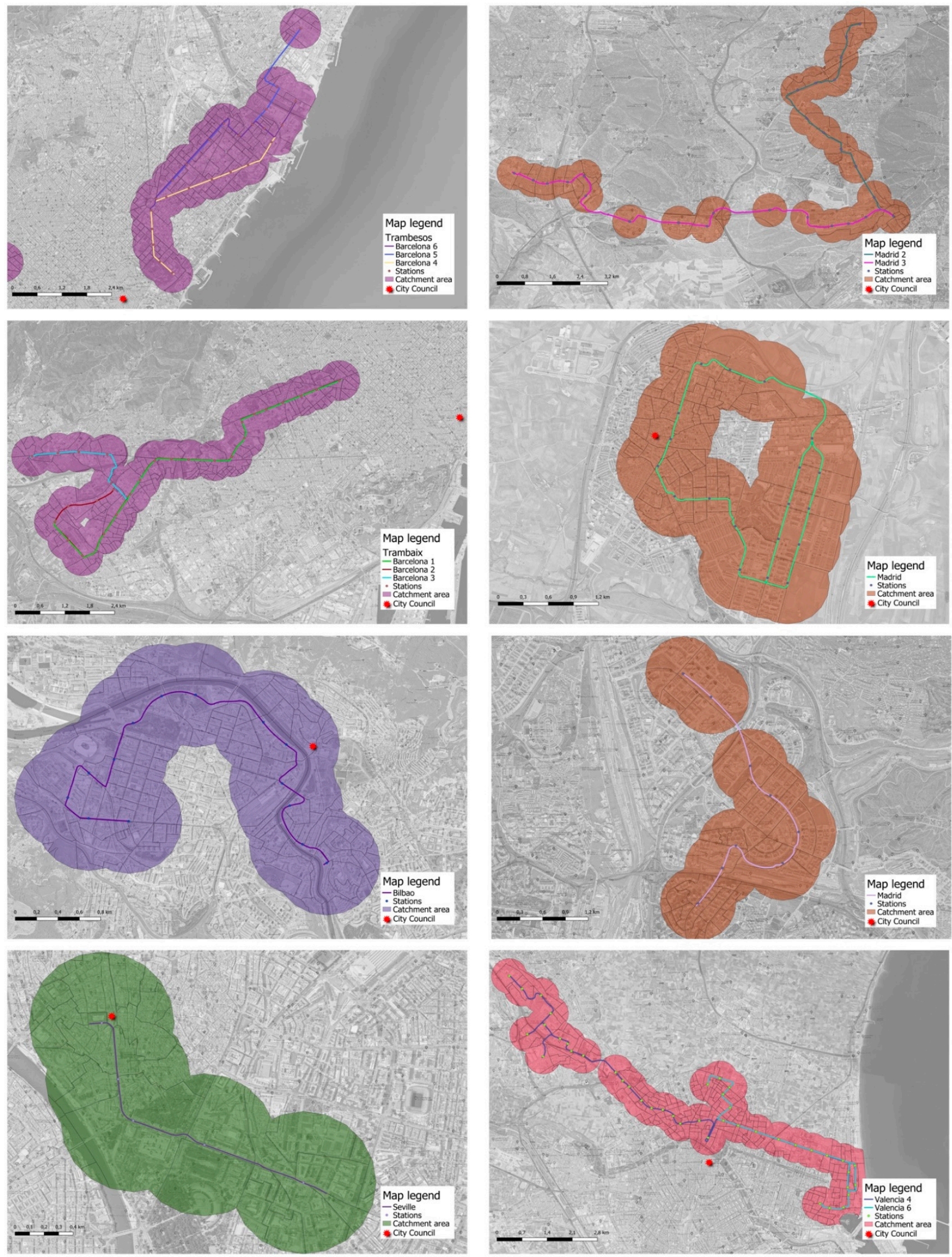

Figure 4. Cities in Group 2. Left-hand column: Barcelona; Barcelona; Bilbao; Seville. Right-hand column: Madrid, Madrid, Madrid; Valencia. 

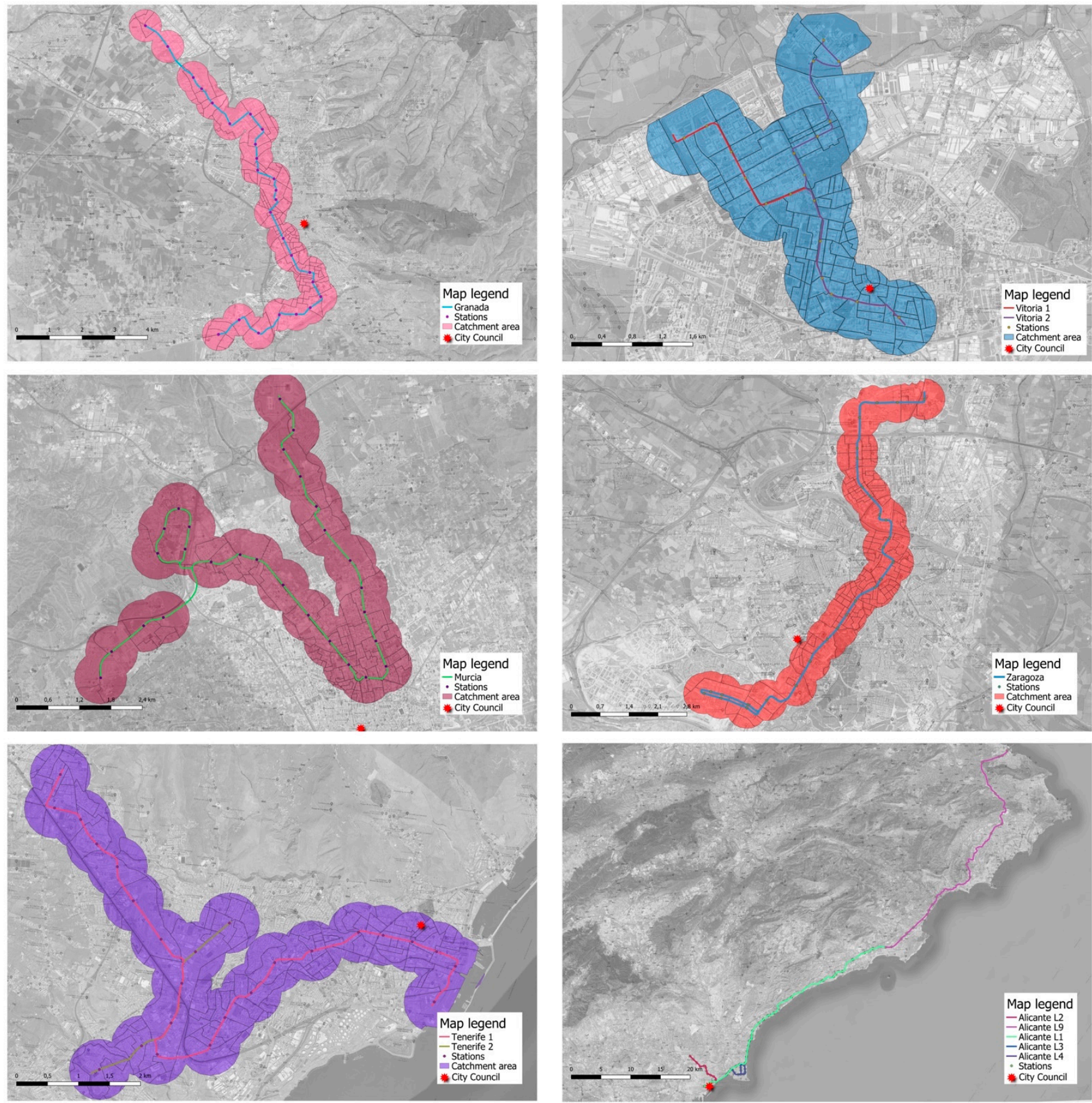

Figure 5. Cities in Groups 1 and 3. Left-hand column: Granada, Murcia, Tenerife; right-hand column: Vitoria, Zaragoza, Alicante.

\section{Results and Discussion}

The results enabled us to find out several things. In Group I (Table 3), annual users varied from 5.10 million in Murcia to 28.2 in Zaragoza. The shortest length was $12.72 \mathrm{~km}$ (Vitoria) and the longest, $18 \mathrm{~km}$ (Murcia). Systems usually had one or two lines where stations were located a mean distance of $400 \mathrm{~m}$ to $666 \mathrm{~m}$ away from each other. Potential users (people who live no more than $500 \mathrm{~m}$ from a station) varied from almost 18,000 in Vitoria to almost 30,000 in Tenerife. Daily users per station (from 1525 in Zaragoza to 325 in Murcia) and acceptance rate, which varied from $42 \%$ in Murcia to $226 \%$ in Zaragoza were more representative. The population density in the capture areas was never below 
1514 pop $/ \mathrm{km}^{2}$. Lastly, the ratio of passengers per unit line varied from 2.20 in Zaragoza to 0.28 in Murcia.

Table 3. Group 1 results.

\begin{tabular}{|c|c|c|c|c|c|c|}
\hline & & Granada & Murcia & Tenerife & Vitoria & Zaragoza \\
\hline 1 & $\begin{array}{l}\text { Annual service users } \\
\text { (million pax) }\end{array}$ & 10.20 & 5.10 & 14.10 & 8.30 & 28.20 \\
\hline 2 & Line length $(\mathrm{km})$ & 15.90 & 18.00 & 16.10 & 12.72 & 12.80 \\
\hline 3 & Number of lines (units) & 1.00 & 2.00 & 2.00 & 2.00 & 1.00 \\
\hline 4 & Number of stations (units) & 26.00 & 28.00 & 25.00 & 20.00 & 33.00 \\
\hline 5 & Number shared stations (units) & 0.00 & 1.00 & 2.00 & 6.00 & 0.00 \\
\hline 6 & Capture area $\left(\mathrm{km}^{2}\right)$ & 14.08 & 14.33 & 12.79 & 7.06 & 11.76 \\
\hline 7 & Potential users (pop) & $26,131.00$ & $21,705.00$ & $29,713.00$ & $17,900.00$ & $22,286.00$ \\
\hline 8 & Daily users (pax) & $18,214.29$ & 9107.14 & $25,178.57$ & $14,821.43$ & $50,357.14$ \\
\hline 9 & Users per station & 700.55 & 325.26 & 1.007 .14 & 741.07 & 1525.97 \\
\hline 10 & Acceptance rate & $70 \%$ & $42 \%$ & $85 \%$ & $83 \%$ & $226 \%$ \\
\hline 11 & Density of capture area & 1855.89 & 1514.65 & 2323.14 & 2535.41 & 1895.07 \\
\hline 12 & $\begin{array}{l}\text { Mean distance between } \\
\text { stations }(\mathrm{m})\end{array}$ & 636.00 & 666.67 & 644.00 & 530.00 & 400.00 \\
\hline 13 & Passengers per unit line & 0.64 & 0.28 & 0.88 & 0.65 & 2.20 \\
\hline
\end{tabular}

In Group 2 (Table 4), the ranges were wider. Annual users varied from 29.10 million in Barcelona to 2.99 million in Bilbao. The shortest system was in Seville $(3.97 \mathrm{~km})$ and the longest in Barcelona $(29.20 \mathrm{~km})$. The network composition varied from one line to six in the whole Barcelona system, although distributed between subway and light rail. The mean distance between stations varied from $405 \mathrm{~m}$ in Valencia to 685 in Madrid. Potential users varied from a little over 2000 in Seville to over 46,000. Users per station also varied widely, from 355 in Valencia to 1417 in Seville, and also the acceptance rate, which was 26\% in Bilbao compared to $426 \%$ in Madrid. We also note that the population density in the capture areas was hardly 251 in Madrid while it was 4002 in Bilbao. Finally, the ratio of riders per unit of line varied from 1.80 in Zaragoza to 0.42 in Valencia. Table 4 also shows data for Group 3, which as mentioned, includes only the city of Alicante.

Table 4. Results for Groups 2 and 3.

\begin{tabular}{|c|c|c|c|c|c|c|c|}
\hline & & Barcelona & Bilbao & $\begin{array}{l}\text { Group } 2 \\
\text { Madrid }\end{array}$ & Seville & Valencia & $\begin{array}{l}\text { Group } 3 \\
\text { Alicante }\end{array}$ \\
\hline 1 & Annual service users (million pax) & 29.10 & 2.99 & 16.90 & 3.97 & 8.80 & 11.10 \\
\hline 2 & Line length (km) & 29.20 & 5.57 & 35.64 & 2.20 & 21.10 & 112.60 \\
\hline 3 & Number of lines (unit) & 6.00 & 1.00 & 4.00 & 1.00 & 3.00 & 5.00 \\
\hline 4 & Number of stations (units) & 53.00 & 14.00 & 55.00 & 5.00 & 43.00 & 69.00 \\
\hline 5 & Number shared stations (units) & 10.00 & 0.00 & 1.00 & 0.00 & 12.00 & 9.00 \\
\hline 6 & Capture area $\left(\mathrm{km}^{2}\right)$ & 23.36 & 5.06 & 28.20 & 2.62 & 20.03 & 40.52 \\
\hline 7 & Potential users (pop) & $22,287.00$ & $20,255.00$ & 7080.00 & 2165.00 & $46,428.00$ & $30,638.00$ \\
\hline 8 & Daily users (pax) & 51.964 .29 & 5.339 .29 & 30.178 .57 & 7.089 .29 & 15.714 .28 & 19.821 .43 \\
\hline 9 & Users per station & 980.46 & 381.38 & 548.70 & 1.417 .86 & 365.45 & 287.27 \\
\hline 10 & Acceptance rate & $233 \%$ & $26 \%$ & $426 \%$ & $327 \%$ & $34 \%$ & $65 \%$ \\
\hline 11 & Density of capture area & 954.07 & 4.002 .96 & 251.06 & 826.34 & 2317.92 & 756.12 \\
\hline 12 & Mean distance between stations (m) & 512.18 & 428.46 & 685.38 & 550.00 & 405.77 & 1.542 .47 \\
\hline 13 & Passengers per unit line & 1.00 & 0.54 & 0.47 & 1.80 & 0.42 & 0.10 \\
\hline
\end{tabular}

The results show some interesting aspects of this characterization. First, it would be hard to imagine an LRT in a city with population densities of less than $1500 / \mathrm{km}^{2}$ on consolidated urban land. This figure is lower when the system is a feeder or complements a conventional subway system, or when it is a tram-train system. Not in vain, light rail transit systems are limited to cities of at least a certain population: Santa Cruz de Tenerife 
is the smallest city of the group (over 210,000 inhabitants). With that in mind, a list of the public rail transportation systems in Spanish cities over 200,000 inhabitants has been included (Table 5), and a frontier in cities over 325,000 inhabitants is more or less marked, including the future and uncommon BTR system in Las Palmas (there is no one in Spain for the moment). A second step emerges, delimited by 325 and 200 thousand: cities in that group can have or have not an LRT system, but definitely not a conventional metro system.

Table 5. Existence of metro and/or LRT in the main Spanish cities (municipalities which are part of a metropolis already cited are not included).

\begin{tabular}{|c|c|c|c|}
\hline City & $\begin{array}{l}\text { Population in Thousands } \\
\text { (1 January 2021) }\end{array}$ & Metro/LRT & Notes \\
\hline Madrid & 3305 & Metro and LRT & \\
\hline Barcelona & 1636 & Metro and LRT & \\
\hline Valencia & 789 & Metro and LRT & \\
\hline Seville & 684 & Metro and LRT & \\
\hline Zaragoza & 675 & LRT & \\
\hline Málaga & 577 & Metro & \\
\hline Murcia & 460 & LRT & \\
\hline Palma & 419 & Metro & \\
\hline Las Palmas & 378 & - & Future BTR [84] \\
\hline Bilbao & 346 & Metro and LRT & \\
\hline Alicante & 337 & Tram-train & \\
\hline Córdoba & 322 & - & - \\
\hline Valladolid & 297 & - & - \\
\hline Vigo & 293 & - & - \\
\hline Gijón & 268 & - & Future train system [85] \\
\hline Vitoria & 253 & LRT & \\
\hline A Coruña & 245 & - & - \\
\hline Elche & 234 & - & - \\
\hline Granada & 231 & LRT & \\
\hline Oviedo & 217 & - & - \\
\hline Cartagena & 216 & - & - \\
\hline $\begin{array}{l}\text { Jerez de la } \\
\text { Frontera }\end{array}$ & 212 & - & Future tram-train [6] \\
\hline $\begin{array}{l}\text { Santa Cruz } \\
\text { de Tenerife }\end{array}$ & 208 & LRT & \\
\hline Pamplona & 203 & - & - \\
\hline Almería & 200 & - & - \\
\hline
\end{tabular}

In Group 1, the data for Zaragoza are surprising: the users of that line double those of the following LRT, Tenerife, while at the same time, such parameters as density of capture area or length of line are not particularly noteworthy. This leads to high numbers in those parameters directly related to users (acceptance rate, users per station, passengers per unit line). One possible reason for this success may be due to another noteworthy fact of this LRT: the mean distance between stations is noticeably shorter than the rest. Therefore, one possible explanation stems from the shorter distance between stations and points of origin/destination of trips. In this sense, it may be observed that Murcia is extreme in both categories, so there might be a relationship between the mean distance between stations and acceptance rate. Figure 6 shows such an equivalence showing a certain logic: even Tenerife could be due to the city being a coastal city, which in practice, means that there are no points $500 \mathrm{~m}$ from stations. 


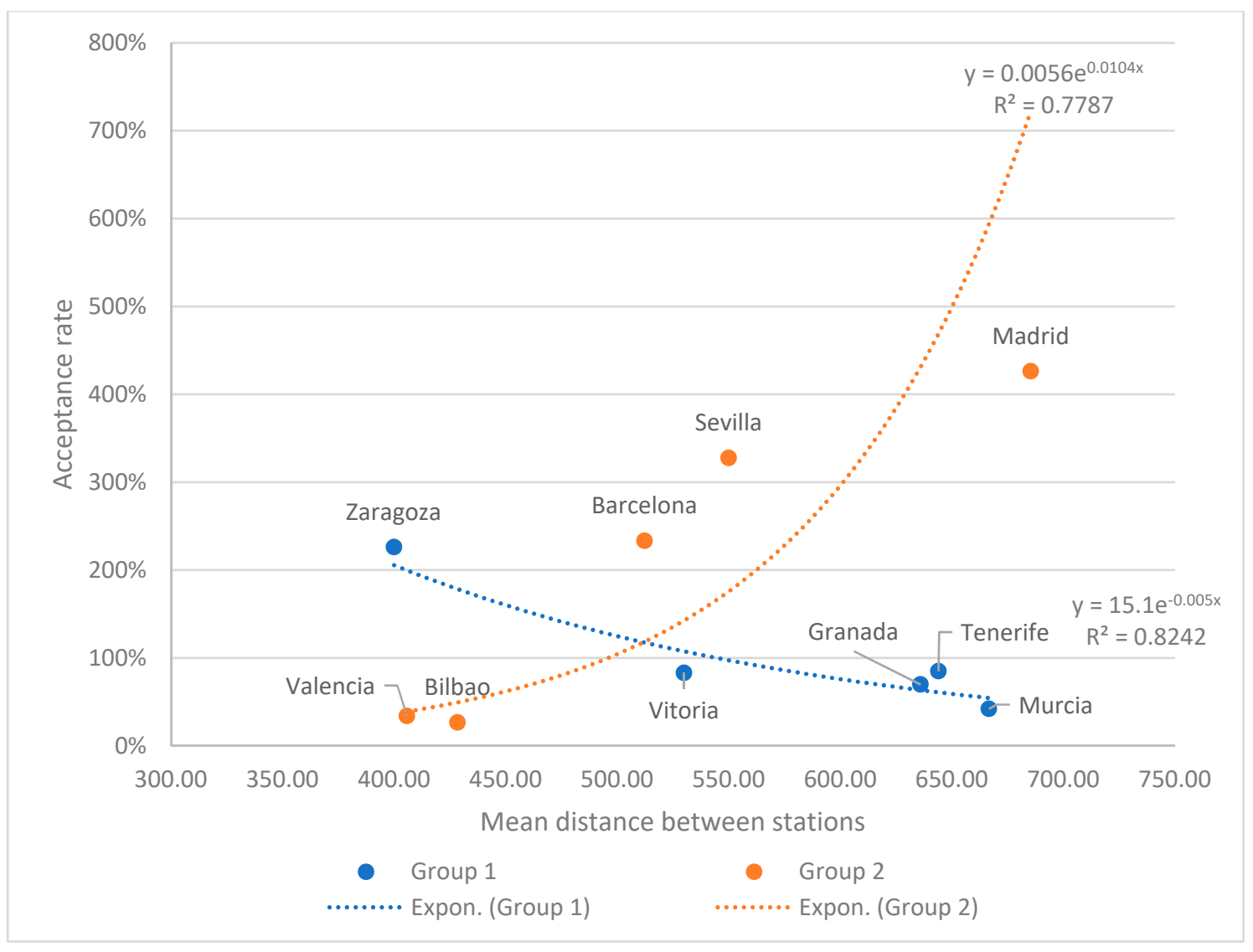

Figure 6. Relationship between acceptance rate and mean distance between stations for Groups 1 and 2.

That figure also shows the values associated with Group 2. In this case, it might be thought that there is an inverse relationship between the distance between stations and the acceptance rate (which would be absurd), but in reality, this relationship does not make sense because the systems compared are not similar. Compared to Group I, in which LRTs are the main urban transit system, Group 2 includes very dissimilar LRTs that depend on the importance of the conventional subway system. Barcelona and Madrid have excellent subway networks, which are among the major worldwide systems; Seville is a unique line because it is reduced to a route through the touristic city center; in Valencia and Bilbao they are less important lines complementing subway systems in middle-size cities in the European context. However, there is a certain similarity in these last two cities.

In terms of LRT with transfer stations, in Group 1 there are three cases: Tenerife and Vitoria have their transfer stations in the center of the systems, while Murcia main line has a transfer station with the so-called shuttle line. Group 2 LRT schemes are complements of the main metro system. While in Madrid, Barcelona or Valencia LRT lines are mainly in the periphery, in Seville or Bilbao the line is in the very center or in Barcelona. Therefore, a clear pattern for transfer stations cannot be stablished.

Another interesting trend is the continuity of the total catchment areas. Being the mean distance between stations under the aforesaid distance of $500 \mathrm{~m}$, buffers drawn on consecutive stations tends to intersect one to others. That means a relevant number of users could choose more than one station for riding the LRT. Moreover, a second question emerges: cities are usually compact, so transportation systems have continuity and regularity in the distance between stations.

In terms of line scheme, Murcia presents again an unusual form (Figure 5), with two sections of the same line nearly parallel; there is a distance of $700 \mathrm{~m}$ up to $1300 \mathrm{~m}$ on foot, so many potential trips could be more rapid and efficient on foot, rather than by LRT. This 
could be another explanation for the lower values of this scheme, in comparison with the others.

\section{Conclusions}

The study reported here proposed the characterization of the LRT systems operating in Spain by determining the values of a series of parameters associated with city geometry, potential and daily users, users per station, acceptance rate, density of catchment areas, or passengers per unit line. Data has been obtained by using QGIS software, and also after research on the official census and on the operator's annual reports.

The main result is the data range obtained. These values show the geometrical picture of the LRT schemes concerning lines, stations and users. These data could be useful in future studies and preliminary projects carried out in other Spanish cities interested in introducing an LRT in their urban grid, and also for comparison with LRT in other countries. As seen in the literature review section, some LRT systems planned in different Spanish cities were finally cancelled due to doubts on the final success of the infrastructure. Moreover, questions concerning the access distances to and from the stations, transfer penalties or oversized projects (and therefore economically unviable) have been set as the main problems related to failed projects. In the analysis, clear differences between the Zaragoza and Murcia LRT success have been exposed, and variances on geometrical values have emerged. Furthermore, results have also proved the differences between cities with LRT as main transportation system, and cities whose LRT scheme complements the subway net: data results are dissimilar in these two circumstances, and also transfer stations works different. Finally, the research has stablished a method and a group of parameters to define LRTs.

The limitations of this study that should be mentioned are, first, those associated with the sample size which is not very large. A larger sample could reinforce our conclusions. At the same time, other studies on LRTs mentioned at the beginning of this article, are limited to two [14], three [7] and five cases [50], so actually this study is quite complete by comparing to others. It would also be of interest to study the relationship of LRTs to other transportation networks, such as commuter trains or city and metropolitan buses, or ride car parks.

Future work could be in three directions. First, other technical parameters, such as those associated with service quality, could be studied. In this group, stations (roofed or not, seating space, real information on traffic), commercial speed, the distance of the LRT to points of interest in the city, schedules and frequencies, number of seats per vehicle, etc. Second, comparative studies with LRTs in other countries could be carried out to evaluate any similarities or differences. For example, we compared the results of our study with the one on the Turkish LRT carried out several years ago [50], which had some parameters in common with ours (Table 6). Thus, in Turkey, daily service users of the smallest system (Samsum) exceeded 20,000, compared to 5000, 7000 or 9000 in some systems in Spain. The users per station varied in Turkey from 995 to 5700, while only in Barcelona, Seville, Tenerife and Zaragoza did they surpass 995. The stations in Turkey were somewhat farther apart than in Spain (although not by much), and the ratio of riders per unit line varied from 0.75 and 5.09 in Turkey, compared to the range of 0.10 to 2.20 in Spain, where only the systems in Barcelona, Seville, Tenerife and Zaragoza surpass those 0.75 minimums. Apparently, therefore, the Turkish systems are more successful insofar as capturing passengers, although one basic point missing to be able to compare these parameters with more assurance is the population density in the systems' capture areas. Thirdly and lastly, research on the influence of a new LRT in tourism figures (as explained above, LRT cultivates an image of the city as progressive and modern), in the labor market, in the generation of new business or even in the expansion of new residential neighborhoods could be quantified. For that, again, GIS and data on these themes seem to be the right tool for developing a method. 
Table 6. Data for Turkey, based on [50].

\begin{tabular}{cccccc}
\hline & Ankara & Bursa & Adana & Kayseri & Samsum \\
\hline Annual service users & 35.59 & 63.87 & 24.84 & 14.60 & 11.71 \\
$\quad$ (million pax) & 8.70 & 30.50 & 17.40 & 14.20 & 15.70 \\
Length of lines (km) & 11.00 & 31.00 & 28.00 & 13.00 & 21.00 \\
Number of stations (unit) & $63,553.57$ & $114,053.57$ & $44,357.14$ & $26,071.43$ & $20,910.71$ \\
Daily users (pax) & 5777.60 & 3679.15 & 1584.18 & 2005.49 & 995.75 \\
Users per station (pax) & $538-994$ & $600-800$ & $800-1000$ & $400-800$ & $600-800$ \\
Mean distance between & 4.09 & 2.09 & 1.43 & 1.03 & 0.75 \\
$\quad$ stations (m) & & & & &
\end{tabular}

Author Contributions: Introduction: E.P.-F. and P.P.-L.; literature review: E.P.-F. and P.P.-L.; study area: E.P.-F. and P.P.-L.; materials and methods: E.P.-F. and P.P.-L.; results and discussion: E.P.-F. and P.P.-L.; conclusions: E.P.-F. and P.P.-L. All authors have read and agreed to the published version of the manuscript.

Funding: This research was developed within the research project SV-21-GIJON-1-22, funded by the IUTA (Gijon Council and Universidad de Oviedo) with a total of $€ 1.760$.

Institutional Review Board Statement: Not applicable.

Informed Consent Statement: Not applicable.

Data Availability Statement: The data presented in this study are available on request from the corresponding author. The data are not publicity available. The data were obtained on the basis of own research.

Conflicts of Interest: The authors declare no conflict of interest.

\section{References}

1. Vigarié, A. Le tramway de Nantes: Un exemple d'utilisation des transports en commun pour contrôler et orienter l'urbanisation. Gèocarrefour 1983, 58, 41-50. [CrossRef]

2. Bottoms, G.D. Continuing development in light rail transit in Western Europe-United Kingdom, France, Spain, Portugal and Italy. In Proceedings of the 9th National Light Rail Transit Conference, Portland, Oregon, 16-18 November 2003 ; pp. 713-728.

3. Matsoukis, E. The Role of a Feasibility Study in Planning A New LRT System. In Proceedings of the WIT Transactions on The Built Environment; WIT Press: Southampton, UK, 2003; pp. 25-32.

4. Lane, B.W. Significant characteristics of the urban rail renaissance in the United States: A discriminant analysis. Transp. Res. Part A Policy Pract. 2008, 42, 279-295. [CrossRef]

5. Giménez, I. Once empresas concurren para redactar el proyecto del futuro tranvía. Diario de Noticias. 12 April 2006. Available online: https: / / web.archive.org/web/20060526090227/ (accessed on 4 December 2021).

6. Redacción. El Tranvía completa otro de los hitos pendientes al adjudicar a Renfe el contrato de pre-explotación por 4,2 millones. Diario de Cádiz. 17 December 2021. Available online: https:/ / www.diariodecadiz.es/noticias-provincia-cadiz/tranvia-completahito-adjudicar-Renfe-contrato-pre-eexplotacion-video_0_1642036290.html (accessed on 4 December 2021).

7. Olesen, M. Framing light rail projects-Case studies from Bergen, Angers and Bern. Case Stud. Transp. Policy 2014, 2, 10-19. [CrossRef]

8. Cervero, R. Journal Report: Light Rail Transit and Urban Development. J. Am. Plan. Assoc. 1984, 50, 133-147. [CrossRef]

9. Handy, S. Smart Growth and the Transportation-Land Use Connection: What Does the Research Tell Us? Int. Reg. Sci. Rev. 2005, 28, 146-167. [CrossRef]

10. Edwards, M.; Mackett, R.L. Developing new urban public transport systems. Transp. Policy 1996, 3, 225-239. [CrossRef]

11. Huang, R.; Moudon, A.V.; Zhou, C.; Stewart, O.T.; Saelens, B.E. Light rail leads to more walking around station areas. J. Transp. Health 2017, 6, 201-208. [CrossRef]

12. Casello, J.; Lewis, G.; Yeung, K.; Santiago-Rodríguez, D. A Transit Technology Selection Model. J. Public Transp. 2014, 17, 50-75. [CrossRef]

13. Mackett, R.; Babalik Sutcliffe, E. New urban rail systems: A policy-based technique to make them more successful. J. Transp. Geogr. 2003, 11, 151-164. [CrossRef]

14. Whitney, W.J.; O'Mahony, M.M. Transport planning in Dublin and Edinburgh. Proc. Inst. Civ. Eng. Transp. 1999, 135, 163-170. [CrossRef]

15. Kołoś, A.; Taczanowski, J. The feasibility of introducing light rail systems in medium-sized towns in Central Europe. J. Transp. Geogr. 2016, 54, 400-413. [CrossRef] 
16. Sekasi, J.; Martens, M.L. Assessing the Contributions of Urban Light Rail Transit to the Sustainable Development of Addis Ababa. Sustainability 2021, 13, 5667. [CrossRef]

17. Mehanović, M. Guidelines for transformation of trams to the light rail system in Sarajevo. Sci. Eng. Technol. 2021, 1, 42-51. [CrossRef]

18. Chamseddine, Z.; Ait Boubkr, A. Exploring the place of social impacts in urban transport planning: The case of Casablanca City. Urban Plan. Transp. Res. 2020, 8, 138-157. [CrossRef]

19. Li, H.; Peng, J.; Liu, W.; Huang, Z. Stationary Charging Station Design for Sustainable Urban Rail Systems: A Case Study at Zhuzhou Electric Locomotive Co., China. Sustainability 2015, 7, 465-481. [CrossRef]

20. Pacheco-Raguz, J.F. Assessing the impacts of Light Rail Transit on urban land in Manila. J. Transp. Land Use 2010, 3, 113-138. [CrossRef]

21. Abidoye, R.B.; Fam, F.; Oshodi, O.S.; Oyetunji, A.K. Impact of light rail line on residential property values-A case of Sydney, Australia. Int. J. Hous. Mark. Anal. 2021; ahead-of-print. [CrossRef]

22. Falamarzi, A.; Moridpour, S.; Nazem, M. A time-based track quality index: Melbourne tram case study. Int. J. Rail Transp. 2021, 9 , 23-38. [CrossRef]

23. Lee, J.; Boarnet, M.; Houston, D.; Nixon, H.; Spears, S. Changes in Service and Associated Ridership Impacts near a New Light Rail Transit Line. Sustainability 2017, 9, 1827. [CrossRef]

24. Park, E.S.; Sener, I.N. Traffic-related air emissions in Houston: Effects of light-rail transit. Sci. Total Environ. 2019, 651, 154-161. [CrossRef]

25. Alade, T.; Edelenbos, J.; Gianoli, A. A Sustainable Approach to Innovation Adoption in Light-Rail Transport. Sustainability 2020 12, 1262. [CrossRef]

26. Schoner, J.; Cao, X. Walking for Purpose and Pleasure. Transp. Res. Rec. J. Transp. Res. Board 2014, 2464, 67-76. [CrossRef]

27. Páez, A.; Whalen, K. Enjoyment of commute: A comparison of different transportation modes. Transp. Res. Part A Policy Pract. 2010, 44, 537-549. [CrossRef]

28. Roberts, J.; Hu, M.; Saksvig, B.; Brachman, M.; Durand, C. Examining the Influence of a New Light Rail Line on the Health of a Demographically Diverse and Understudied Population within the Washington, D.C. Metropolitan Area: A Protocol for a Natural Experiment Study. Int. J. Environ. Res. Public Health 2018, 15, 333. [CrossRef]

29. Pulugurtha, S.S.; Srirangam, L.P. Pedestrian safety at intersections near light rail transit stations. Public Transp. 2021, 1-26. [CrossRef]

30. Credit, K. Transit-oriented economic development: The impact of light rail on new business starts in the Phoenix, AZ Region, USA. Urban Stud. 2018, 55, 2838-2862. [CrossRef]

31. Lin, J.; Chen, T.; Han, Q. Simulating and Predicting the Impacts of Light Rail Transit Systems on Urban Land Use by Using Cellular Automata: A Case Study of Dongguan, China. Sustainability 2018, 10, 1293. [CrossRef]

32. Fan, Y.; Guthrie, A.E.; Levinson, D.M. Impact of light rail implementation on labor market accessibility: A transportation equity perspective. J. Transp. Land Use 2012, 5, 28-39. [CrossRef]

33. Sovacool, B.K.; Yazdi, A.H. Technological frames and the politics of automated electric Light Rail Rapid Transit in Poland and the United Kingdom. Technol. Soc. 2019, 59, 101190. [CrossRef]

34. Ferbrache, F.; Knowles, R.D. City boosterism and place-making with light rail transit: A critical review of light rail impacts on city image and quality. Geoforum 2017, 80, 103-113. [CrossRef]

35. Van Der Bijl, R.; Van Oort, N.; Bukman, B. Light Rail in Bird's Eye View. In Light Rail Transit Systems; Elsevier: Amsterdam, The Netherlands, 2018; pp. 1-15.

36. Van Der Bijl, R.; Van Oort, N.; Bukman, B. Making Light Rail. In Light Rail Transit Systems; Elsevier: Amsterdam, The Netherlands, 2018; pp. 155-196.

37. Ibrahim, A.N.H.; Borhan, M.N.; Md. Yusoff, N.I.; Ismail, A. Rail-based Public Transport Service Quality and User Satisfaction-A Literature Review. Promet Traffic Transp. 2020, 32, 423-435. [CrossRef]

38. Chowdhury, S.; Ceder, A. Users' willingness to ride an integrated public-transport service: A literature review. Transp. Policy 2016, 48, 183-195. [CrossRef]

39. Shen, W.; Xiao, W.; Wang, X. Passenger satisfaction evaluation model for Urban rail transit: A structural equation modeling based on partial least squares. Transp. Policy 2016, 46, 20-31. [CrossRef]

40. Ibrahim, A.N.H.; Borhan, M.N.; Mat Yazid, M.R.; Rahmat, R.A.; Yukawa, S. Factors Influencing Passengers' Satisfaction with the Light Rail Transit Service in Alpha Cities: Evidence from Kuala Lumpur, Malaysia Using Structural Equation Modelling. Mathematics 2021, 9, 1954. [CrossRef]

41. De Oña, J.; de Oña, R.; Eboli, L.; Mazzulla, G. Perceived service quality in bus transit service: A structural equation approach. Transp. Policy 2013, 29, 219-226. [CrossRef]

42. Kingham, S.; Dickinson, J.; Copsey, S. Travelling to work: Will people move out of their cars. Transp. Policy 2001, 8, 151-160. [CrossRef]

43. Galdames, C.; Tudela, A.; Carrasco, J.-A. Exploring the Role of Psychological Factors in Mode Choice Models by a Latent Variables Approach. Transp. Res. Rec. J. Transp. Res. Board 2011, 2230, 68-74. [CrossRef]

44. Guo, Z.; Wilson, N.H.M. Modeling Effects of Transit System Transfers on Travel Behavior. Transp. Res. Rec. J. Transp. Res. Board 2007, 2006, 11-20. [CrossRef] 
45. Albalate, D.; Bel, G.; Fageda, X. When supply travels far beyond demand: Causes of oversupply in Spain's transport infrastructure. Transp. Policy 2015, 41, 80-89. [CrossRef]

46. Donaire, G. El tranvía de Jaén, 120 millones tirados a una vía muerta. El País. 26 May 2013. Available online: https://elpais.com/ ccaa/2013/05/24/andalucia/1369396376_116395.html (accessed on 4 December 2021).

47. Vila, Á. Caballero, tajante sobre el regreso del tranvía a Vigo: “Las ciudades que lo hicieron quebraron". Metropolitano Gal. 3 February 2021. Available online: https:/ / metropolitano.gal/enfoque/caballero-tajante-sobre-el-regreso-del-tranvia-a-vigo-lasciudades-que-lo-hicieron-quebraron/ (accessed on 4 December 2021).

48. Lamas, J. Un metro llamado ligero que el viento se llevó. La Voz Galicia. 8 November 2021. Available online: https://www. lavozdegalicia.es/noticia/vigo/vigo/2021/11/09/metro-llamado-ligero-viento-llevo/0003_202111V9C8991.htm (accessed on 4 December 2021).

49. Kim, K.W.; Lee, D.W.; Chun, Y.H. A comparative study on the service coverages of subways and buses. KSCE J. Civ. Eng. 2010, 14, 915-922. [CrossRef]

50. Vitosoglu, Y.; Ozden, R.; Yaliniz, P.; Bilgic, S. Comparison of Light Rail Systems in Turkey with the Method of Comparative Standard Determination. Transp. Res. Procedia 2014, 3, 670-679. [CrossRef]

51. Alpkokin, P.; Topuz Kiremitci, S.; Black, J.A.; Cetinavci, S. LRT and street tram policies and implementation in turkish cities. J. Transp. Geogr. 2016, 54, 476-487. [CrossRef]

52. Van der Bijl, R.; Utsunomiya, K.; van Oort, N. Failed projects offer valuable lessons for future schemes. Int. Railway J. 2020. Available online: https://www.railjournal.com/in_depth/failed-projects-valuable-lessons-future-schemes (accessed on 4 December 2021).

53. Monzón de Cáceres, A.; López García de Léaniz, C.; Del Cuvillo, R.; Julio Castillo, R.; Sánchez Sacristán, C.M. Observatorio de la Movilidad Metropolitana. Available online: http://www.observatoriomovilidad.es/es/publicaciones/informes.html (accessed on 8 March 2020).

54. Martín Urbano, P.; Ruiz Rúa, A.; Sánchez Gutiérrez, J.I. El sistema de transporte público en España: Una perspectiva interregional. Cuad. Econ. 2012, 31, 195-228.

55. Navarro-Ligero, M.L.; Valenzuela-Montes, L.M. The performance of planning hypotheses about urban-transport futures: The Light Rail Transit in Granada. Transp. Res. Procedia 2019, 41, 596-608. [CrossRef]

56. Talavera García, R.; Valenzuela Montes, L.M.; Soria Lara, J.A. Evaluando la influencia de la calidad de la distancia peatonal en la cobertura de paradas del metro ligero de Granada (España). Bol. La Asoc. Geógr. Españoles 2018, 79, 1-25. [CrossRef]

57. Jiménez-Torrecillas, A.; Hernández-Soriano, R.; Ruiz, L.M.; Rodríguez-Aguilera, A.; Tienza, C.; Garzón, F.; Carvajal, R.; SánchezLópez, A.; Moreno, J.D. Integración de restos arqueológicos Almohades en el metropolitano de Granada. La investigación multidisciplinar para el proyecto y desarrollo de infraestructuras contemporáneas en los centros históricos. Inf. Constr. 2014, 66, e036. [CrossRef]

58. Andersen, J.L.E.; Landex, A. Catchment areas for public transport. WIT Trans. Built Environ. 2008, 101, $175-184$.

59. Cervero, R.; Kang, C.D. Bus rapid transit impacts on land uses and land values in Seoul, Korea. Transp. Policy 2011, 18, 102-116. [CrossRef]

60. Hess, D.B. Walking to the bus: Perceived versus actual walking distance to bus stops for older adults. Transp. 2012, 39, 247-266. [CrossRef]

61. Park, S.; Deakin, E.; Jang, K. Can Good Walkability Expand the Size of Transit-Oriented Developments? Transp. Res. Rec. J. Transp. Res. Board 2015, 2519, 157-164. [CrossRef]

62. Ewing, R.; Cervero, R. Travel and the Built Environment. J. Am. Plan. Assoc. 2010, 76, 265-294. [CrossRef]

63. Cervero, R.; Kockelman, K. Travel demand and the 3Ds: Density, diversity, and design. Transp. Res. Part D Transp. Environ. 1997, 2, 199-219. [CrossRef]

64. Sarker, R.I.; Mailer, M.; Sikder, S.K. Walking to a public transport station. Smart Sustain. Built Environ. 2019, 9, 38-53. [CrossRef]

65. Ma, X.; Jin, Y.; He, M. Measuring Bikeshare Access/Egress Transferring Distance and Catchment Area around Metro Stations from Smartcard Data. Information 2018, 9, 289. [CrossRef]

66. Hess, D.B.; Almeida, T.M. Impact of Proximity to Light Rail Rapid Transit on Station-area Property Values in Buffalo, New York. Urban Stud. 2007, 44, 1041-1068. [CrossRef]

67. Oluyomi, A.O.; Knell, G.; Durand, C.P.; Mercader, C.; Salvo, D.; Sener, I.N.; Gabriel, K.P.; Hoelscher, D.M.; Kohl, H.W. Foot-based audit of streets adjacent to new light rail stations in Houston, Texas: Measurement of health-related characteristics of the built environment for physical activity research. BMC Public Health 2019, 19, 238. [CrossRef]

68. Kuby, M.; Barranda, A.; Upchurch, C. Factors influencing light-rail station boardings in the United States. Transp. Res. Part A Policy Pract. 2004, 38, 223-247. [CrossRef]

69. Fajri, F.M.; Sumabrata, J. Analysis of Transit Oriented Development Potential on Light Rail Transit Palembang, Simpang Polda Station Area. MATEC Web Conf. 2019, 259, 5003. [CrossRef]

70. O'Sullivan, S.; Morrall, J. Walking Distances to and from Light-Rail Transit Stations. Transp. Res. Rec. J. Transp. Res. Board 1996, 1538, 19-26. [CrossRef]

71. Ortega Ortiz, C. Estudio de Viabilidad, Anteproyecto, Proyecto Constructivo de Referencia, Documentación Ambiental, Plan de Explotación y Programa Económico de una Línea de Tranvía Este-Oeste en Zaragoza; University of Zaragoza: Barcelona, Spain, 2017. 
72. Gutiérrez, J.; García-Palomares, J.C. Distance-Measure Impacts on the Calculation of Transport Service Areas Using GIS. Environ. Plan. B Plan. Des. 2008, 35, 480-503. [CrossRef]

73. Magalhães, M.T. Spatial coverage index for assessing national and regional transportation infrastructures. J. Transp. Geogr. 2016, 56, 53-61. [CrossRef]

74. Furth, P.G.; Mekuria, M.C.; SanClemente, J.L. Stop Spacing Analysis Using Geographic Information System Tools with Parcel and Street Network Data. Transp. Res. Rec. J. Transp. Res. Board 2007, 2034, 73-81. [CrossRef]

75. Banai, R. Transit Station Area Land Use/Site Assessment with Multiple Criteria: An Integrated GIS-Expert System Prototype. J. Public Transp. 2000, 3, 95-110. [CrossRef]

76. Bhuyan, I.A.; Chavis, C.; Nickkar, A.; Barnes, P. GIS-Based Equity Gap Analysis: Case Study of Baltimore Bike Share Program. Urban Sci. 2019, 3, 42. [CrossRef]

77. Miller, H.J.; Shaw, S.-L. Geographic Information Systems for Transportation in the 21st Century. Geogr. Compass 2015, 9, 180-189. [CrossRef]

78. Breje, M.; Bilaşco, Ş.; Roşca, S.; Fodorean, I.; Vescan, I. GIS spatial analysis model for access time to public health infrastructure. Case study: Arad County, Romania. In Proceedings of the International Multidisciplinary Scientific GeoConference: SGEM, Albena, Bulgaria, 28 June-9 July 2019; pp. 865-872.

79. Hamed, M.M.; Easa, S.M. Integrated Modeling of Urban Shopping Activities. J. Urban Plan. Dev. 1998, 124, 115-131. [CrossRef]

80. Prasertsri, N.; Sangpradid, S. Parking Site Selection for Light Rail Stations in Muaeng District, Khon Kaen, Thailand. Symmetry 2020, 12, 1055. [CrossRef]

81. Farooq, A.; Xie, M.; Stoilova, S.; Ahmad, F.; Guo, M.; Williams, E.J.; Gahlot, V.K.; Yan, D.; Mahamat Issa, A. Transportation Planning through GIS and Multicriteria Analysis: Case Study of Beijing and XiongAn. J. Adv. Transp. 2018, 2018, 1-16. [CrossRef]

82. Farooq, A.; Xie, M.; Stoilova, S.; Ahmad, F. Multicriteria Evaluation of Transport Plan for High-Speed Rail: An Application to Beijing-Xiongan. Math. Probl. Eng. 2019, 2019, 1-23. [CrossRef]

83. Tejedor, S.D. El 53,5\% de los gijoneses estará a menos de 15 minutos de una estación. El Comercio. 10 March 2021. Available online: https:/ / www.elcomercio.es/gijon/gijoneses-minutos-estacion-20210310001620-ntvo.html (accessed on 4 December 2021).

84. Redacción. El Mitma Destina otro Millón de Euros al Proyecto de la MetroGuagua de Las Palmas de Gran Canaria; Europa Press: London, UK, 2022; Available online: https:/ / www.europapress.es/islas-canarias / noticia-mitma-destina-otro-millon-euros-proyectometroguagua-palmas-gran-canaria-20220104134455.html (accessed on 4 December 2021).

85. Redacción. Un Proyecto Conjunto Fijará Plazos Para El Plan de Vías y El Metrotrén. Mi Gijón. 15 December 2021. Available online: https:/ / migijon.com/proyecto-conjunto-fijara-plazos-plan-vias-metrotren-gijon/ (accessed on 4 December 2021). 